$\frac{\text { RCCS }}{\text { Annual Review }}$

\section{RCCS Annual Review}

A selection from the Portuguese journal Revista Crítica de Ciências Sociais

4 | 2012

Issue no. 4

\title{
Social Costs: Where Does the Market End?
}

\section{Vítor Neves}

Translator. Sheena Caldwell

\section{CpenEdition}

\section{Journals}

Electronic version

URL: http://journals.openedition.org/rccsar/443

DOI: $10.4000 /$ rccsar.443

ISSN: $1647-3175$

\section{Publisher}

Centro de Estudos Sociais da Universidade de Coimbra

Electronic reference

Vítor Neves, « Social Costs: Where Does the Market End? », RCCS Annual Review [Online], 4 | 2012,

Online since 01 October 2012, connection on 10 December 2020. URL : http://

journals.openedition.org/rccsar/443; DOI : https://doi.org/10.4000/rccsar.443 


\section{Vítor Neves}

School of Economics and Center for Social Studies, University of Coimbra, Portugal

\section{Social Costs: Where Does the Market End? ${ }^{*}$}

The markets are a powerful economic coordination mechanism. Even so, their limitations cannot, and should not, be ignored. The wide range of costs originating from business activities within the framework of capitalism and subsequently externalised or, more accurately, transferred to other agents or to society as a whole with no repercussions on the price mechanism, is one particularly striking example of these limitations. This article contrasts the different concepts of social costs existing in economics literature, ranging from the identification of the problem as a "market failure" to the more heterodox (and less wellknown) concept of $\mathrm{K}$. William Kapp, according to whom social costs are an intrinsic and inevitable problem within the institutional context of capitalism. The nature of the problem is discussed initially, followed by a presentation, albeit brief, of two fundamental fault lines separating the prevailing conventional approach and Kapp's heterodox one: the concept of efficiency adopted and the way in which the question of valuation of social costs is viewed.

Keywords: social costs; externalities; market failures; market; efficiency; social value.

\section{Introduction}

In a stimulating book published recently, entitled The Value of Nothing, Raj Patel very clearly illustrates, by means of several examples, the diversity, range and above all the importance of social costs resulting from business activities within the framework of contemporary capitalism (Patel, 2011, in particular ch. 3). The truth is, however, that our understanding of these costs and how to deal with them in terms of public policy is still far from settled.

Conventional economic theory regarding social costs, which stems from A. C. Pigou's The Economics of Welfare (1932 [1920]) but lacks his subtlety of analysis, is based on the understanding that these costs are "externalities" - a market failure. This approach, which remained relatively uncontroversial until the early 1960s, was substantially challenged by the work of Ronald Coase in "The Problem of Social Cost" (1960). According to this author, rather than market failure, the problem of social costs is, in fact, the result of the nonexistence of markets, either because the property rights that would make them viable are not clearly assigned, or because the transaction costs (the costs of market functioning) are prohibitive. In both approaches, however, social costs are reduced merely to a problem of the inefficient allocation of economic resources. Moreover, although it represents a

\footnotetext{
* Article published in RCCS 95 (December 2011).
} 
significant paradigm shift in the analysis of social costs (Medema, 1994), Coase's analysis may still be considered canonical, essentially using the conceptual framework and analytical tools of traditional microeconomic theory. It is not therefore surprising that it features in nearly all microeconomics and public economics textbooks used nowadays in universities throughout the world.

On the fringes of this prevailing line of thought, the work of Karl William Kapp merits attention. A distinguished, but relatively unknown, critical economist in the tradition of American institutionalism whose ideas were strongly rooted in European thought, Kapp dedicated most of his academic work to the problem of social costs for more than a quarter of a century. In a seminal book, The Social Costs of Private Enterprise, ${ }^{1}$ and various subsequent works, Kapp shows that social costs are an inexorable product of the intrinsic logic of capitalism, with unavoidable political dimensions, and he questions the search for solutions to the problem of social costs via the market (as Coase tends to argue) or economic calculations based on market prices (as was also the case with Pigou).

In order to clarify the nature of the problem from the outset, it is therefore important to confront these different concepts of social costs. This will be the aim of the next section, in which particular attention will be paid to K. William Kapp, given the reader's presumed relative lack of familiarity with his work. The section which follows this aims to present, albeit briefly, two essential fault lines between the conventional approach to social costs and the heterodox approach of K. William Kapp, namely (1) the relevant concept of efficiency and (2) the problem of the valuation of social costs. The text ends with some concluding remarks.

\section{The Nature of the Problem}

\subsection{Social costs as "externalities" (market failure)}

In conventional economics literature, social costs are externalities. ${ }^{2}$ The latter are understood as the unplanned consequences of the activities of one or more economic agents (individuals or firms) ${ }^{3}$ which affect the well-being or productive capacity of others

\footnotetext{
${ }^{1}$ The book was first published in 1950, and a revised edition appeared in 1963 under the title The Social Costs of Business Enterprise.

${ }^{2}$ Negative externalities. Similarly, we may refer to positive externalities when the issue is one of social benefits, rather than costs.

${ }^{3}$ The specific origin of the externality - whether production or consumption - is irrelevant.
} 
involved in the economic process, for which it is not possible to obtain or demand compensation. ${ }^{4}$ They are residual or secondary ${ }^{5}$ effects of the main economic activity of the agent - "external" effects - which escape the working of the price mechanism. They are external economies or diseconomies.

The basic problem here is the inability of the price mechanism to assure a compensation for the damage (or benefits) caused or, in the language of economists, to internalise these effects. ${ }^{6}$ It is a market failure or, in other words, a situation in which the markets prove incapable of ensuring the "efficient" allocation of economic resources. Within the dominant analytical framework of economics this is equivalent to saying that the Pareto optimum has been violated. ${ }^{7}$ If there can be no compensation, within the logic of the potential Pareto improvement test, that is, in situations in which the damage caused by the action of an agent is greater than the advantages it offers to another agent or economic sector, it is impossible to achieve "optimality." ${ }^{\prime 8}$ Externalities therefore represent a problem for which corrective action is justifiable. ${ }^{9}$ In the Pigouvian tradition, this generally means state intervention in the form of taxes, subsidies or state regulation.

\subsection{Social costs as the result of a lack of markets}

Ronald Coase rejects the idea of social costs as external damage (thus also rejecting the term "externalities"). In his view, it is wrong to consider the problem of social costs as the result of damage imposed unilaterally on others and as a question of lack of compensation

\footnotetext{
${ }^{4}$ Damages not perceived as such by the various economic actors in question are not considered externalities. Environmental degradation, for example, only represents a significant problem when people feel that it affects their well-being (Franzini, 2006: 58).

${ }^{5}$ See, for example, Fernandes (2011: 140).

${ }^{6}$ The effects on third parties internalised by the action of the price mechanism - the so-called pecuniary externalities - are, from this point of view, irrelevant. They are not even considered true externalities. They are part of the normal functioning of the market. This is the case, for example, with the negative effects on the well-being of local residents in a tourist area due to price increases during the holiday season as a result of the large influx of tourists.

${ }^{7}$ A situation is considered to be Pareto optimal (or Pareto efficient) if it is not possible to improve the level of well-being of one given economic agent without implying a reduction in the well-being of at least one other agent.

${ }^{8}$ On the potential Pareto improvement test and the Kaldor-Hicks compensation criterion, see, for example, Bromley (1990) and Zerbe Jr. (2001).

${ }^{9}$ Only the externalities relevant from the point of view of the Pareto optimum are of interest. If, for example, a firm's decision adversely affects the well-being of its workers or the community, but the damage caused is lesser than the improvement of the well-being of its shareholders, there is no justification, within the logic of efficiency (the only relevant argument within the framework of this approach), for any corrective measures.
} 
(internalisation) from the agent generating the damage to the agent(s) bearing the damage. Ultimately, everyone is responsible for the existence of the problem and for resolving it.

Social costs result from situations in which the agents involved establish a reciprocal relationship with regard to the object of the damage. In a relationship between two agents, A and B, "both parties cause the damage." Preventing damage to B implies causing damage to $A$. There are costs for both parties. It is therefore desirable for both to take the damage into consideration when deciding on their course of action (Coase, 1960: 13).

The question which should be asked, as Coase seeks to demonstrate using several examples of actual legal cases, is: should A be allowed to harm B or should B be allowed to harm A? It is a matter of deciding whose interests will be protected by law and by the courts, i.e., which interests will acquire the status of rights (Medema, 1994: 69). These rights have a dual nature (Medema, 1994: 68-69; 2009: 105): granting a right to one party implies exposing others to the effects of exercising this right, which implies costs. ${ }^{10}$

Rather than a market failure, for Coase social costs reveal a problem of non-existence of markets resulting from a failure to define the property rights that permit (and facilitate) transactions. This is, in the end, a failure of the state (Medema, 1996: 102). Once these rights have been clearly assigned, (voluntary) transactions may take place in favour of those who value them most, leading, in the absence of transaction costs, ${ }^{11}$ to a Pareto efficient allocation regardless of the initial attribution of property rights. The problem ceases to exist. This is the famous result known as the "Coase theorem."

In reality, however, given the unavoidable empirical relevance of transaction costs preventing the realisation of the theorem in practical terms - what is really important, according to Coase, is not that this result, so highly prized by market enthusiasts (and a great many economics textbooks) represents the solution, but rather the essential role played by the law (and the courts) in allocating economic resources. Due to the prohibitive cost of negotiation, rights tend to be exercised under the terms of their initial attribution - "rights stick where they hit" (Medema, 1994: 76).

According to Coase, the answer to the question of to whom property rights should be assigned is clear: the damage which is greatest should be avoided (Coase, 1960: 2). Rather

\footnotetext{
10 "The cost of exercising a right is always the loss which is suffered elsewhere in consequence of the exercise of that right - the inability to cross land, to park a car, to build a house, to enjoy a view, to have peace and quiet or to breathe clean air" (Coase, 1960: 44).

${ }^{11}$ The costs of market functioning.
} 
than placing the entire burden on those "responsible" for the damage and trying by all means possible to eliminate this damage, the solution to the problem of social costs lies in choosing the most advantageous alternative. It is an exercise in calculating gains and losses. It involves knowing whether the gains that result from preventing the damage are greater or lesser than the losses caused by measures designed to eliminate it (Coase, 1960: 27). For example, if river pollution kills fish, the value of the loss of the fish should be compared with the value of the production made possible by the activity causing the pollution. The ground rule for making decisions, Coase argues, is to choose the situation that maximises the total value of production.

This obviously implies knowing the value of what is acquired and what is sacrificed. According to Coase (1970a: 35), "it is not always, or ever, easy to decide which course [of action] to take. But the nature of choice is clear." Continuing in his own words, it is a decision that "is no different from deciding whether a field should be used for growing wheat or barley, and it is certainly not one about which we should show any great emotion. It is a difficult and important question, but it is certainly just a question of valuation" (Coase, 1970b: 9, my italics).

To sum up, in redefining the nature of the problem, Coase also questions two fundamental aspects of the traditional approach to externalities: 1) the idea that social costs correspond to "market failure"; 2) the understanding that the solution to the problem inevitably involves "corrective" measures by the state, namely taxes and subsidies. Yet, as will become clear later, this reasoning is still based on traditional microeconomic theory.

\subsection{Social costs as a problem intrinsic to capitalism}

In various essential aspects K. William Kapp's analysis of social costs represents a break with previous approaches. In his view, social costs are business costs transferred to third parties or the community as a whole and "unpaid" (or "uncompensated") by the agents who produce them. They are widespread, though very dissimilar, phenomena in capitalist economies, intrinsically linked to production and inevitable within the framework of profitbased economies. They are, nevertheless, costs that may be minimised through reforms and appropriate institutional changes.

According to Kapp, the existence of social costs is fundamentally due to the fact that the search for profit results in an emphasis on minimising the private costs of production. In 
minimising their internal costs, companies will tend to transfer to third parties and the community in general, and effectively maximise, social costs (that is, the portion of the total costs usually termed "external" costs in traditional economics literature).

Rather than the mere residual or secondary effects of a main activity - an undesirable coproduct - social costs are instead an intrinsic and necessary feature of profit-based economies. The capitalist economy is, in Kapp's words, an "economy of unpaid costs".

These costs cover a broad range of environmental and social diseconomies, including such diverse and heterogeneous aspects as environmental pollution, the depletion of renewable resources and the exhaustion of non-renewable resources, urban congestion, deteriorating working conditions, workplace accidents and occupational diseases, the harmful effects of technological change, economic instability and unemployment and, as has begun to emerge with particular acuteness during the course of the current crisis, the sacrifice of individuals' well-being to the rhythms, interests and demands of the economic machine. They include, in fact, a wide "variety of 'diseconomies', increased risks and uncertainties which may extend far into the future" (Kapp, 1963: 185).

In a recent re-reading of Kapp's work, Maurizio Franzini (2006) argues that Kappian social costs should be understood as violations of basic social rights, or even a reversal of these rights. It is therefore completely irrelevant whether the damage caused by the action of an agent, measured as losses in the well-being of those who suffer them, are greater or lesser than the advantages they bring to those who produce them (a central question, as we have seen, in the framework of the conventional analysis of externalities). As the author emphasises, social costs are violations of social rights, perpetrated by market capitalism, whether they occur in a Pareto efficient context or not. The social damage, even if less than the gains for companies, still represents a violation of social rights and for this very reason is no less important.

According to Kapp, the free operation of the market promotes the "externalisation" or, as he prefers to call it, the large scale shifting of a significant part of the total cost of production to the community (the conversion of "external" costs into social costs).

The possibilities of "resistance" to this shift of costs by negotiating conflicting interests following a Coasean line of thought - are, in Kapp's view, limited. There are several reasons which may explain this. Kapp (1978 [1963]: 267-268) suggests the following: 
(i) Some social costs, such as the damage caused to human health, may remain hidden (and ignored by those affected) for long periods of time;

(ii) In the case of catastrophes such as floods, landslides and other "natural" disasters caused, or at least aggravated, by the irrational use of resources, social costs, and all the human suffering they imply, may be perceived as the result of merely natural causes;

(iii) Certain kinds of damage, although significant overall, are spread out over a large number of people in such a way that individual losses are relatively negligible, and therefore do not appear to justify "defensive action";

(iv) Those directly affected by social costs may not have the (financial, legal or other) means to act in the appropriate way, namely by resorting to legal channels, to prevent the damage that is being inflicted upon them from continuing;

(v) In general, those affected are in an inferior bargaining position and thus are less able to resist the power of companies and their organisations; for the latter, lobbying to prevent regulatory measures from being applied to their business activities is frequently more profitable than adopting measures to prevent social costs;

(vi) Finally - and this is perhaps the most fundamental question - social costs are, as a rule, an inexorable product of the logic of the working of the market economy as a whole.

In fact, Kapp contests the idea that social costs can, in general, be reasonably conceived within a framework of bilateral and reciprocal relations. In his view, social costs are associated with asymmetrical non-market relationships which are often involuntary, shaped by relatively powerful entities that impose their interests on the economically and politically weaker sectors of society. Economic actors have different opportunities to access the relevant information and different capacities for controlling or even manipulating this information, as well as unequal bargaining power. The problem of social costs therefore includes a dimension of power, and therefore politics - which is ignored by the dominant theory - without which it cannot be fully understood.

At this point it is worth quoting Kapp himself: 
[T] he fact that part of the costs of production can be shifted to third persons or to society as a whole is merely another way of saying that costs and hence profits depend at least to some extent on the power of the individual firm to do so. In short, what the conventional theory treats as given is in fact already the result of a constellation of market or non-market interdependencies between units of a heterogeneous character and with different degrees of economic control and domination. (Kapp, 1969: 335, my italics)

Some years later, in one of his final works, Kapp would add:

$[T]$ he causal process is not, as a rule, bilateral in character, with specific polluters causing damage to specific, identifiable individuals or affected parties. In fact, the process has nothing in common with a typical two-persons, market relationship; it is not the result of any voluntary contractual transaction. The affected persons are as a rule without protection; they have no voice in the matter; they are victims of a process over which they have little if any control. The degradation of the quality of the environment happens, so to speak, behind their backs, and the possibilities of redress are limited or ineffective under prevailing compensation laws. (Kapp 1977: 531, my italics)

This brings us to a central feature of Kapp's approach: the idea that the causal processes that link production, the natural and social environment and individuals involve "economic" and "non-economic" dimensions within a complex network of systemic interdependencies.

In his view, social costs are the result of the combined action of a plurality of factors, relations and causal processes, and can only be fully understood (and their effects minimised) within the framework of an approach that recognises (1) the open nature of socioeconomic systems, and (2) the circular and cumulative nature of these causal processes (Kapp, 1976). Their cumulative nature demands that consideration be given to critical thresholds (or critical zones), which is lacking in conventional analyses, on the basis of which social costs acquire a new relevance and meaning. Linear cause and effect mechanisms and theoretical approaches based on the conventional notion of equilibrium prove inadequate for analysing social costs.

\section{Fault lines}

There are many differences - some more significant than others - between the various approaches to social costs. I intend to highlight two of these which, in my view, represent fundamental fault lines between the dominant conventional approach and Kapp's radically heterodox approach. The first difference has to do with the concept of efficiency underlying 
the two approaches; the second refers to the problem of valuation. In both cases we can see the central position the market assumes in the thinking of the authors under analysis. ${ }^{12}$

In fact, the question of social costs is, from start to finish, a discussion about the place of the market. Daniel Bromley offers a good summary of the prevailing position amongst economists concerning the role of the market:

[T] he centrality of markets is so pronounced in economics that instances in which markets do not (or cannot) work are regarded as cases of market failure - with the immediate implication that we should see what is necessary for markets to be established. Or, we derive the outcome that would obtain if a market could but be established. (Bromley, 1997: 1389)

Kapp's position is very different: for him, what is important above all is to consider the limits of the market. One thing is certain: discussing the problem of social costs inevitably means discussing the role of the market (in theory and in terms of the reality of our economic systems). It is a complex question and, obviously, this text cannot accommodate a detailed discussion of all its aspects. In the sections which follow, the intention is simply to outline the terms of the debate.

\subsection{Pareto efficiency vs. social efficiency}

Despite their differences, traditional analyses of social costs, such as the one produced by Coase, have one essential point in common: they conceive of social costs as a problem of economic efficiency (a retreat from the Pareto optimum). Even when it is acknowledged, as Coase does, that efficiency does not rule out the question of choice criteria and that "problems of welfare economics must ultimately dissolve into a study of aesthetics and morals" (Coase, 1960: 43), from the viewpoint of the economist, it all comes down to deciding, with the aim of preventing the more serious damage, whether the gain resulting from preventing damage is greater or lesser than the loss arising out of any measures designed to eliminate it. Questions of efficiency and equity remain on two completely separate levels. In strictly economic terms, only efficiency matters - the aggregate gains in terms of the production of goods (commodities). ${ }^{13}$ Questions associated with the

\footnotetext{
${ }^{12}$ The issue of power and the asymmetry of agents, which features in Kapp's work, as opposed to the idea of voluntary transactions between equal parties within a framework of reciprocity, as argued by Coase, also represents a fault line between the two approaches, as I have suggested elsewhere (Neves, 2012).

${ }^{13}$ Considerations of efficiency and equity were both present in the work of Pigou. However, the question of the impossibility of interpersonal comparisons of utility raised by Robbins (1932) would translate, with the development of the Kaldor-Hicks criterion of potential Pareto improvement in the late 1930s, into the strict separation of these two normative criteria (see Zerbe Jr., 2001). Gradually the profession began to internalize
} 
distribution of income and social well-being belong to the sphere of ethics, in which the economist has no expertise.

Kapp rejects this view as being strictly formal, static, partial and incomplete, even to the point of classifying it as "empty" and "ambiguous" (Kapp, 1965: 305-306). In his judgment , it does not provide minimally adequate criteria for assessing the relative success or failure of any solution to the problem of social efficiency, since it does not (and cannot) take into consideration the institutional context, the relevance of the variables of (historical) time and (social) space, the possibilities of institutional change, or the real needs and basic requirements of human life. In addition, it also erroneously assumes a false dichotomy between "economic" and "non-economic" purposes.

Kapp's entire analysis of social costs is, in fact, based on the idea that what matters is maximising the benefits of economic activity - understood as social values - with a minimum of social costs. It is a problem of social efficiency. For Kapp, as for J. M. Clark before him, referring to social efficiency means considering overall economic performance from the point of view of the values of society, which implies defining substantive (rather than merely formal) criteria and objective indicators of well-being based on a substantive theory of essential human needs and behaviour.

Even so, according to Kapp, such indicators do not dispense with the need for a strong element of collective deliberation and political decision-making with regard to the social values and objectives to be pursued. Social costs are, above all, a problem that concerns the institutional organisation of the economy. They constitute a collective problem whose resolution demands collective responses.

\subsection{The question of valuation}

As we have seen, within the conventional framework, the problem of social costs is, in the end, reducible to a problem of valuation. Coase was crystal clear in this respect: it is a matter of determining the value of costs and benefits based on information supplied by market prices, and choosing the solution that maximises the net benefits.

the (erroneous) idea that efficiency, unlike equity, could be considered value free. As Bromley states (1990: 93), "because efficiency derives from production, because greater production of goods and services is thought not to imply any value judgements, and because production can be weighted by market prices - which are themselves considered to be neutral - efficiency becomes synonymous with objective analysis." 
The practical difficulties of this undertaking are well known, particularly with regard to attributing value to non-market goods, as are the philosophical objections to the monetisation of human life and the awareness that, in certain cases, attributing a monetary value is, to say the least, questionable. But for most economists this is no more than a necessary and inevitable use of a convenient yardstick ("the measuring rod of money"), without which rational choice is considered impossible. In the words of Pearce, "like it or not, any decision implies a monetary valuation" (1978: 3).

For Coase, market prices and, more generally, the possibility of using a monetary yardstick, are at the core of economic analysis. Actually, it is this possibility that in his view gives it the advantage, in comparison with other disciplines, in analysing the workings of the economic system (Coase, 1994 [1977]).

For Kapp, however, social costs, like social benefits, have to be considered extra-market phenomena (Kapp, 1970). Monetary criteria, such as the principle of willingness to pay or accept compensation on the basis of market prices, are unsuitable for evaluating social costs and the consequent deliberations on the course of action to be followed. Since marketgenerated prices do not adequately reflect the relative importance of human needs, the relative scarcity of production factors and the actual total costs of production, as indicators they are "not only imperfect and incomplete; they are misleading" (Kapp, 1970: 843-844).

It is therefore imperative, according to Kapp, to evaluate costs and benefits in terms of the value they have to society (their "value to society") ${ }^{14}$. Market price and social value are far from being one and the same thing. For the author, constructing a theory of social value constitutes the central problem of economic theory (Kapp, 1978 [1963]: 293), and this involves defining objective criteria for what is necessary and essential to human life and survival - his essential reference point - and a new social accounting.

\section{Final observations}

The markets - and the prices they generate - represent a powerful economic coordination mechanism. However, as this text should have made clear, they have considerable limitations. The wide range of costs "externalised" by companies within the framework of

\footnotetext{
14 "Value to society" and not "value in society," in the apt words of J. M. Clark (2009 [1936]: 61), from whom Kapp borrowed the concept.
} 
contemporary capitalism, with no repercussions on the price mechanism and on decisions regarding the allocation of resources, are a particularly striking example of these limitations.

For most economists, this is undoubtedly an important economic problem - the problem of externalities, as it is generally termed in conventional economics literature - which demands a response in terms of defining public policies. Various solutions have been identified. In some cases they favour state measures, such as the so-called Pigouvian taxes or the regulation of private economic activities, whilst in other cases they are based on the definition of property rights and the creation of markets, such as the well-known example of the trading of greenhouse gas emission allowances. However, for these economists, "externalities" do not threaten the basic theoretical foundations of traditional economic analysis, namely economic calculation based on market prices or analyses of efficiency based on the Pareto optimum.

K. William Kapp's approach to social costs is very different, as we have seen. According to this author, in addition to constituting a fundamental and unavoidable economic problem within capitalist economies, social costs are an enormous challenge to contemporary economic science. If social costs originate from within the capitalist market economy, the solution to the problem must transcend the logic of the market.

In the words of the editors of Social Costs and Public Action in Modern Capitalism, an indispensable collection of texts inspired by Kapp's work,

By focusing on the market as the only possible economy, formal theory implicitly favours those economic and social interests that have most to gain from a disembedded market. [...] Societal goals should be a priority for the economy - and the economy should be an enhancement of social opportunities - rather than a constraint. Thus, the performance of the economy should be valuated in terms of the societal opportunities that it can achieve. (Elsner et al., 2006: 8)

This is a complex and difficult exercise, but undoubtedly one worth undertaking.

Translated by Sheena Caldwell

Revised by Teresa Tavares

\section{References}

Bromley, Daniel (1990), "The Ideology of Efficiency: Searching for a Theory of Policy Analysis," Journal of Environmental Economics and Management, 19: 86-107.

Bromley, Daniel (1997), "Rethinking Markets," American Journal of Agricultural Economics, 79(5): 1383-1393. 
Clark, John M. (2009), Preface to Social Economics: Economic Theory and Social Problems, in Moses Abramovitz and Eli Ginzberg (eds.). New Brunswick: Transaction Publishers [1 ${ }^{\text {st }}$ ed.: 1936].

Coase, Ronald (1960), "The Problem of Social Cost," The Journal of Law \& Economics, 3 (October): 144.

Coase, Ronald (1970a), "Social Cost and Public Policy," in George Edwards (ed.), Exploring the Frontiers of Administration: Six Essays for Managers. Toronto: York University, Faculty of Administration Studies, Bureau of Research, 33-44.

Coase, Ronald et al. (1970b), The Legal and Economic Aspects of Pollution. A Discussion by University of Chicago Faculty Members. Chicago: The University of Chicago Center for Policy Study.

Coase, Ronald (1994), "Economics and Contiguous Disciplines," in Ronald Coase, Essays on Economics and Economists. Chicago: The University of Chicago Press, 34-46 [1 $1^{\text {st }}$ ed.: 1977].

Elsner, Wolfram; Frigato, Pietro; Ramazzotti, Paolo (eds.) (2006), Social Costs and Public Action in Modern Capitalism: Essays Inspired by Karl William Kapp's Theory of Social Costs. London: Routledge.

Fernandes, Abel Costa (2011), Economia pública - Eficiência económica e teoria das escolhas colectivas. Lisbon: Edições Sílabo [ $2^{\text {nd }}$ ed.]

Franzini, Maurizio (2006), "Social Costs, Social Rights and the Limits of Free Market Capitalism: A Rereading of Kapp", in Wolfram Elsner, Pietro Frigato and Paolo Ramazzotti (eds.), Social Costs and Public Action in Modern Capitalism: Essays Inspired by Karl William Kapp's Theory of Social Costs. London: Routledge, 56-71.

Kapp, K. William (1963), "Social Costs and Social Benefits - A Contribution to Normative Economics," in Erwin Beckerath and Herbert Giersch (eds.), Probleme der normativen Ökonomik und der wirtschaftspolitischen Beratung. Berlin: Duncker \& Humblot, 183-210.

Kapp, K. William (1965), "Social Economics and Social Welfare Minima," in T.K.N Unnithan et al. (eds.), Towards a Sociology of Culture in India. Essays in Honor of Dr. D. P. Mukerji. New Delhi: Prentice Hall of India, 297-309. Electronic version consulted on 09.03.11 at http://www.kwilliamkapp.de/documents/INDIAPDF.pdf

Kapp, K. William (1969), "On the Nature and Significance of Social Costs," Kyklos, 22(2): 334-347.

Kapp, K. William (1970), "Environmental Disruption and Social Costs: A Challenge to Economics," Kyklos, 23(4): 833-848.

Kapp, K. William (1976), "The Open-System Character of the Economy and its Implications," in Kurt Dopfer (ed.), Economics in the Future. London: Macmillan, 90-105.

Kapp, K. William (1977), "Environment and Technology: New Frontiers for the Social and Natural Sciences," Journal of Economic Issues, 11(3): 527-539.

Kapp, K. William (1978), The Social Costs of Business Enterprise. Nottingham: Spokesman $\left[1^{\text {st }}\right.$ ed.: 1963].

Medema, Steven (1994), Ronald H. Coase. London: Macmillan.

Medema, Steven (1996), "On Pangloss, Pigouvians and Pragmatism: Ronald Coase and Social Cost Analysis," Journal of the History of Economic Thought, 18 (Spring): 96-114.

Medema, Steven (2009), The Hesitant Hand: Taming Self-interest in the History of Economic Ideas. Princeton: Princeton University Press.

Neves, Vítor (2012), "A análise dos custos sociais em Ronald Coase e K. William Kapp: duas perspetivas sobre a economia e a interdisciplinaridade," in Celia Kerstenetzky e Vítor Neves (eds.), Economia e Interdisciplinaridade(s).Coimbra: Edições CES/Almedina (forthcoming). 
Patel, Raj (2011), The Value of Nothing: How to Reshape Market Society and Redefine Democracy. London: Portobello Books Ltd.

Pearce, David (1978), "Introduction," in David Pearce (ed.), The Valuation of Social Cost. London: George Allen \& Unwin.

Pigou, Arthur C. (1932), The Economics of Welfare. London: Macmillan and Co. [1 ${ }^{\text {st }}$ ed.:1920]. Electronic version consulted on 15.01.12 at http://www.econlib.org/library/NPDBooks/Pigou/pgEWCover.html

Robbins, Lionel (1984), An Essay on the Nature and Significance of Economic Science. London: MacMillan [ $3^{\text {rd }}$ ed.; $1^{\text {st }}$ ed.: 1932 ].

Zerbe Jr., Richard (2001), Economic Efficiency in Law and Economics. Cheltenham: Edward Elgar. 